\title{
Embætti landlæknis eftir sameiningu
}

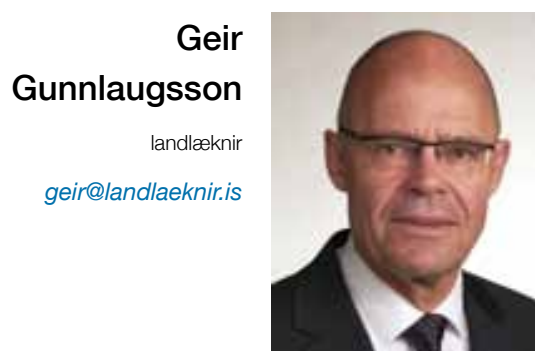

Nú í maí er eitt ár liðið frá pví breytt lög um landlækni og lýðheilsu nr. 41/2007 tóku gildi. Við gildistökuna sameinaðist starfsemi landlæknisembættisins og Lýðheilsustöðvar í Embætti landlæknis. Hugmyndir um að sameina pessar stofnanir höfðu lengi verið til umræðu en formleg vinna við sameiningu hófst í mars 2010, réttum 250 árum frá skipan fyrsta landlæknisins.

Sú sameining sem nú liggur fyrir hefur verið mikilvægur hvati til að ræða og kryfja starf embættisins á grunni laga og reglugerða um markmið og meginhlutverk pess. Nýtt skipurit hvílir á fjórum faglegum stoðum sem eru studdar af stoðsviði og skrifstofu landlæknis sem samhæfir starf pess. Nú starfa 62 starfsmenn í um 53 stöðugildum við embættið.

Svið áhrifapátta heilbrigðis vinnur að heilsueflandi samfélagi sem stuðlar að heilbrigði og vellíðan landsmanna. Forvarnarstarf sem snertir langvinna sjúkdóma og áhrifapætti peirra er eitt helsta viðfangsefni heilbrigðispjónustu um allan heim. Mikilvæg verkefni snerta pví meðal annars lifnaðarhætti, áfengis- og tóbaksvarnir og geðheilbrigði. Sviðið vinnur að pessu með almennum aðgerðum, með pví að próa og styðja við pverfagleg verkefni eins og heilsueflandi leikskóla, grunnskóla og framhaldsskóla. Umsýsla með lýðheilsusjóðnum, arftaka forvarnarsjóðsins, er meðal verkefna sviðsins og styrkveitingar til fjölbreyttra forvarna- og heilsueflingarverkefna og rannsókna.

Svið sóttvarna vinnur í samræmi við sérstök sóttvarnalög og Alpjóðaheilbrigðisreglugerðina. Pó sjúkdómsbyrði sóttvarna hafi hlutfallslega minnkað á síðustu áratugum í hátekjulöndum, einkum vegna bólusetninga og virkra sýklalyfja, má aldrei slá slöku við. Brestur í sóttvörnum getur haft alvarlegar afleiðingar og er kostnaðarsamur, bæði fyrir einstaklinga og samfélög. Vöktun og greining sviðsins felst í pví að fylgjast með hættulegum sjúkdómum og atburðum sem geta haft alvarleg áhrif á líf og heilsu manna. Spítalasýkingar eru vaxandi vandamál fyrir sjúklinga og afar kostnaðarsamar fyrir heilbrigðispjónustuna og við peim parf að bregðast. Bólusetningar eru mikilvæg fyrsta stigs forvörn og skipulag og framkvæmd peirra er meðal verkefna sóttvarnasviðs ásamt eftirfylgd með sýklalyfjaónæmi, kynsjúkdómum og HIV-smiti. Viðbragðsáætlanir við óvæntri heilsuvá falla einnig eðlilega að sóttvarnaverkefnum, eins og reynsla af nýlegum eldgosum og viðbrögð við útblæstri eiturefna ber vitni um.

Svið eftirlits og gæða vinnur að pví að efla gæði og öryggi í heilbrigðispjónustunni. Helstu áherslur sviðsins varða eftirlit með og úttektir á heilbrigðispjónustunni, öryggi og gæðapróun og úrvinnsla kvartana. Unnar eru faglegar kröfur, gæðavísar og önnur viðmið um framkvæmd heilbrigðispjónustu í samstarfi við fagfólk og stjórnvöld. Eftirlitið varðar allar rekstrareiningar heilbrigðispjónustunnar sem eru um 2000 talsins, par af um 400 á ábyrgð lækna í sjálfstæðum rekstri. Lyfjaeftirlit embættisins fellur undir petta svið og hefur að markmiði að styðja við hagkvæma lyfjanotkun og koma í veg fyrir misnotkun. Allar kvartanir eru skoðaðar í pverfaglegum hópi starfsfólks og krufið er til mergjar hvort mistök, vanræksla eða ótilhlýðileg framkoma heilbrigðisstarfsfólks hafi átt sér stað. Niðurstaða slíkrar greiningar getur eðli málsins samkvæmt ekki alltaf hugnast öllum málsaðilum.

Svið heilbrigðisupplýsinga vinnur að pví að safna, greina og túlka gögn um heilsufar og heilbrigðispjónustu, miðla upplýsingum úr gagnasöfnum embættisins og stundar lýðheilsurannsóknir. Helstu áherslur sviðsins varða vinnu við pær 14 heilbrigðisskrár sem embættinu ber að halda, lögum samkvæmt, og styðja samræmda skráningu í heilbrigðispjónustu sem nýtist sem efniviður í heilbrigðisskrár. Opnun á rafrænar gagnasendingar í rauntíma og aðgangur аð gagnvirkum upplýsingum í vöruhúsi gagna eru meðal verkefna sviðsins. Próun rafrænnar sjúkraskrár á landsvísu er á ábyrgð sviðsins síðan 1. mars síðastliðinn. petta umfangsmikla verkefni verður ekki unnið svo vel sé nema í náinni samvinnu við heilbrigðisstarfsfólk og stofnanir heilbrigðispjónustunnar.

Stoðsvið sinnir fræðslu- og kynningarstarfi, eflir innri verkferla og leitast við að veita starfsfólki og peim sem leita til embættisins góða pjónustu. Helstu áherslur sviðsins varða innra öryggis- og gæðastarf, útgáfu og vefsetur, auk skjalavörslu, en mikilvægt er að tryggja skilvirka ferla við umsýslu bréfa og annars sem berst embættinu. Nýr vefur er í burðarliðnum með gjörbreyttri uppbyggingu á efnisflokkum og leitarmöguleikum, en gestir eru um 18.000 á mánuði með um 80-85.000 síðuflettingum.

Embætti landlæknis og starf pess hefur á liðnum misserum verið mjög í brennidepli fjölmiðla og til umræðu á bloggsíðum. Раð ber vott um mikilvægi verkefna embættisins. Starfsfólkið mun hér eftir sem hingað til leggja sig fram við að sinna verkefnum sínum af fagmennsku, einlægni og alúð og málefnaleg gagnrýni hvetur okkur til dáða. Allar ábendingar um pað sem má betur fara eru skoðaðar með opnum huga og reynt að leita lausna. Endurskipulagning stofnunarinnar er ein varða á peirri vegferð að gera embættið betur fært um að sinna fjölbreyttum verkefnum og standa undir réttmætum væntingum sem til pess eru gerðar.

Directorate of Health following a merger 